\title{
Analysis of Teaching Health Education at Primary School
}

Ludmila Fialová ${ }^{*}$

\begin{abstract}
The article deals with the new educational branch Health Education. The research aim was to compare knowledge of basic school pupils after attend of different teaching models. The combination of quantitative and qualitative methods was used in 7. (age 12 year) and 9. class (age 14 year). Researcher elaborate after entrance pupil's questioning a set of didactic manuals on the topic of body care, self-concept, body self-concept and physical activity in education promoting health for the new school subject Health Education. After the practical application of these didactic manuals in the seventh grades of primary school, their effectiveness was verified through a final (output) questionnaire survey and made a comparison with the knowledge of pupils from the ninth grade. The results show significant improvement in pupils' knowledge compared to the entrance questionnaire survey after regular lessons in duration half of year. The knowledge level after introducing the health topics in other subjects (the old teaching model) were significant lower.
\end{abstract}

Keywords: Body care, eating habits, physical activity, self-concept

Özet

\section{İlkokulda Sağlık Eğitimi Öğretiminin Analizi}

Araştırma, Sağlık eğimiyle ilgili yeni bir eğitim dalını kapsamaktadır. Çalışmanın amacı farklı öğretim modelleri uygulanan ilkokul öğrencilerin bilgilerini karşılaştırmaktır. Nicel ve nitel yöntemlerinin bir kombinasyonu 7. (12 yaş) ve 9. sınıftaki (14 yaş) öğrencilerde kullanılmıştır. Araştırmacı yeni başlayan öğrencinin, yeni okuldaki sağlık eğitimi için sağlık eğitimini teşvik eden bir takım öğretici el kitaplarının temel konusu olan, eğitimde vücut bakımı, benlik kavramı, beden benlik kavramı ve fiziksel aktivite gibi konuları sorgulayarak didaktik bir manuel kullanmıştır. $\mathrm{Bu}$ öğretici kılavuzların ilkokulun yedinci sınıfında uygulanmasından sonra, etkinlikleri nihai bir anket yöntemi ile doğrulanmış ve dokuzuncu sınıftan öğrencilerin bilgisi ile karşılaştırma yapılmıştır. Sonuçlar, yarıyıl boyunca düzenli derslere devam öğrencilerin bilgi düzeylerinde, okula girdikleri sırada uygulanan anketlerdeki bilgi se*viyelerine kıyasla belirgin bir iyileşme olduğunu göstermektedir. Diğer derslerde (eski öğretim modeli), sağlık konularını tanıttıktan sonraki bilgi düzeyi kaydadeğer şekilde daha düşüktür.

Anahtar Kelimeler: Benlik kavramı, beslenme alışkanlıkları, fiziksel aktivite, vücut bakımı.

* Prof., Charles University Prague, Faculty of Physical Education and Sport, Czech Republic, fialova@ftvs.cuni.cz 


\section{Introduction}

Health is one of the most important values in our lives. For a long time, the concept of health used to be defined as the absence of disease (WHO, 2012). Therefore, if you are not ill, you are healthy. However, it has turned out that this definition is not very accurate. You are often not ill, but still, you do not feel good, comfortable. Health in a broad sense, in all its aspects, in terms of physical, mental and social health, is the greatest asset of our lives. Being healthy is the first prerequisite to happiness and success.

Education for health in a broad sense may be understood as an effort to promote health and improve the state of health of the population, applied in the process of lifelong learning (Průcha, Walterová, \& Mareš, 2013). It is a summary of educational activities aimed at developing health literacy, which is considered one of the important preconditions for improving the health of individuals, groups and society as a whole. It is essential that health literacy becomes part of education from early childhood, both in families and in schools and school institutions (Holč́k, 2009). In a narrow sense, education for health means a specifically defined educational field which has gradually profiled in the Czech Republic during the ongoing education reforms and has now found its permanent place in the existing curriculum documents (Marádová, 2008a, 2008b).

The educational area of Man and Health has been newly introduced in Czech schools since 2007. It has two branches: Education for Health and Physical Education, which also includes Health Physical Education. The objective of these branches is to guide pupils to the perception of health as the most important value in life, to the understanding of health as a balanced state of physical, mental and social well-being, to the awareness of the issues of health beneficial - hazardous behaviour, to active involvement in activities promoting health (both school and extracurricular ones).

Education for Health is a specifically delimited branch of education defined by educational documents. In the Framework Educational Programme for Primary Education (FEP PE), it is defined as follows: "Education for Health provides basic knowledge about man in relation to preventive health protection. Pupils learn to actively promote and protect health in all its forms (social, mental and physical) and to be responsible for it. Pupils reinforce hygiene, eating, working and other preventive good health habits, develop their refusal skills to avoid harmful substances, injuries and deal with threatening situations in everyday life and emergency situations. They expand and deepen their knowledge of the family, school, and peer community, nature, man, interpersonal relationships and learn to look at their own actions in terms of health needs and life perspectives of a growing up individual, make decisions in favour of health" (FEP PE, 2007, p. 70). 
In the Standard for Primary Education (1995), the branch Health Education (together with the branch Physical Education and Sport), is part of the educational area Human and Health. It is included in the core curriculum at the $1^{\text {st }}$ and $2^{\text {nd }}$ primary school level (pupils in age 6- 15 years). The Health education in this document represents a way towards the formation of one of the most important human values - respect for life and the health of every individual. It seeks to explore the most important favourable and unfavourable influences that can affect human development in the course of one's life and one's current physical and mental state (SPE, 1995).

The school striving to fulfil this mission should create conditions in its educational programme and everyday educational work to ensure that pupils:

- Gradually acquire knowledge and skills that will help them to realize the importance of caring for their own health and the health of others, actively influence their physical, mental and social development and prefer a healthy lifestyle on their scale of values.

- Following the experience of everyday life, learn to understand certain life situations and make correct decisions in matters related to health (daily regime, diet, eating habits, addictive substances), personal safety, partner relationships, sexual behaviour (start of sex life, diseases spread through sexual intercourse, including HIV virus/AIDS), family life, parent ship.

- Improve their skills related to health care, family life and normal household operation, observe basic rules of hygiene and safety, be able to secure personal safety and provide first aid to others.

- Learn how to handle the basics of verbal and non-verbal communication between family members, use appropriate decent language in partner relationships, use professional terminology in relation to sexuality.

- Get advice on sources of information concerning the issues of a healthy lifestyle, seek and find ways to improve their own health in all its components (physical, mental, social, spiritual), to positive thinking.

- $\quad$ Constantly be aware of their belonging to their home and of their changing role in the family (in close relation to the physical, mental and social development), enter adulthood with a responsible approach to health, entering partner relationships and starting their own families.

The above objectives imply that the basis of education in this area is knowledge leading to orientation in the matters of health, to positive thinking and to making right decisions in favour of health, and skills allowing active influencing the physical and mental state of pupils, as well as experience and habits acquired and tested in practical situations of their daily routine (Marádová, 
2007). According to the present-day terminology, this effort could be denoted developing health literacy of pupils.

Education for Health is presently frequently taught by unqualified teachers, which, however, should change shortly - the training of teachers in the branch of Education for Health is already underway. Here, an ideal combination appears to be Physical Education - Education for Health (Mužíková, 2010). The above author presents the results of an opinion survey of primary school headmasters on the implementation of the Education for Health curriculum. This first research analysed the current conditions for the education and implementation of the new subject Education for Health according to the Framework Educational Programme for Primary Education. The surveyed group consisted of 532 headmasters of fully organised primary schools, selected in cooperation with the Czech School Inspection. The survey was conducted during the 2005/2006 school year. The results showed that more than a half of the headmasters of the surveyed primary schools $(56 \%)$ considered the introduction of Education for Health as a separate branch of education beneficial, but most of them considered integrating Health Education with other, traditional subjects Physical Education or Family Education. A third group of the headmasters considered hiring a qualified teacher in the future, while the same number of headmasters would be interested in complementary study in the branch of Health Education. Primary school headmasters would be more interested in short-term courses. The big problem perceived by the surveyed headmasters was the impossibility of providing teaching aids for Health Education where the main reason was the lack of funds.

The branch of Education for Health is currently taught as a separate subject (minimum number of 2 teaching units per week) within the educational programme by $76 \%$ of schools. A potential extension of the number of teaching units within the available units would be used by $53 \%$ of schools. This means that over a half of the surveyed primary schools presently implement Health Education in the form of separate subjects in at least 3 grades of the $2^{\text {nd }}$ level of primary school $=6^{\text {th }}$ to $9^{\text {th }}$ grade (Fialová, Flemr, Marádová, Mužík, 2014).

\section{Research Methodology}

We were interested in pupil's knowledge after attend of different teaching models. This research approach is justified as the introduction of a new branch of education into the school practice poses another serious problem: who will be able to teach subjects with a newly conceived content. Monitoring the content followups in the curriculum may help to search a teacher for a transitional period who will master this task thanks to their professional specialisation, methodological erudition and experience. Based on a specific situation of one primary school, we 
have tried to design teaching topics, prepare didactic materials and analyse their effectiveness in relation to pupils.

The main objective of research at primary school was the elaboration and subsequent verification of the effectiveness of didactic manuals for the subject Health Education (analysis of their contribution to improving the knowledge and skills of pupils in the $7^{\text {th }}$ grade). The research was intended to answer the question: Can the level of knowledge of seventh-grade pupils be raised based on teaching with the help of new didactic manuals compared to the knowledge of ninth-grade pupils who did not go through instruction conceived in this way?

The surveyed sample included seventh-grade pupils (average age of 12.5 yer) of the Second Primary School in Plzeň, a total of 53 pupils. All of them underwent the input and output questionnaire survey. Personal interviews were successively conducted with selected pupils. The final questionnaire was also filled in by 34 ninth-grade pupils (14,7 year old) and, finally, the knowledge was compared.

\section{Used methods}

We used a combination of quantitative and qualitative methods. Among quantitative methods, a questionnaire with 17 questions was selected. Twelve questions were formulated as closed, mostly with options of answers on a 5-point scale. The other questions (5 in all) were structured as open, where pupils themselves were to express their opinion. The data collection took place twice. First, before the start of teaching (September 2011), and, for the second time, half a year later (February 2012). The questionnaire developed for the verification of the effectiveness of the didactic manual was composed of 7 open questions with only one question where pupils chose yes - no options (Hájková, 2012).

The qualitative method was an interview with selected pupils through which we identified deeper contexts. Four pupils (two girls, two boys) responded to the following questions:

- What was the highlight of Health Education's lessons?

- What, on the contrary, did you not like in Health Education lessons?

leave out?

$$
\text { Which activities do you evaluate as the best and which would you }
$$

Do you feel that you did not learn all you wanted to know?

\section{Findings}

\section{Entrance questionnaire survey}

The entrance survey was conducted through questionnaires with the purpose of identifying the level of knowledge in individual topics, the lifestyle 
level which pupils live and their expectations from the subject Health Education. The findings presented the starting point for the elaboration of the working manual designed to help pupils understand the issues and lay solid fundamentals for teaching in the following grades $\left(8^{\text {th }}\right.$ and $\left.9^{\text {th }}\right)$.

The questionnaires were anonymous (to safeguard the truthfulness of responses), pupils only listed their age, sex, height, weight and class $\left(1^{\text {st }}\right.$ part of the questionnaire).

\section{A. Physical activity}

Three questions were asked to investigate what kind of physical activity the pupils were practising and in what amount. It was very interesting to compare the weight of the pupils with the number of hours devoted to physical activity. There, in particular, we could witness that more intensive physical activity was in direct proportion to lower weight.

The next question in the entrance questionnaire identified how many hours per week (excluding school Physical Education) the pupils devoted to physical activity. The amount of physical activity considered sufficient is in the range of 5 hours a week or more. The physical activity of $53 \%$ of the children corresponds to this amount, of them $29 \%$ were engaged in sporting activity for more than 6 hours per week. The children engaged in sporting activities for more than 6 hours a week are involved in some organized sporting activity in a sport club - e.g. volleyball, handball, football clubs, etc. $45 \%$ of the children spend less than 4 hours per week in some physical activity, of them $2 \%$ do not practise any sport for even at least 2 hours per week. This amount of physical activity is insufficient; children are at risk of lifestyle diseases (such as obesity, high blood pressure, etc.). It is, therefore, necessary to explain to the children the necessity and importance of regular physical activity in adequate intensity. We built upon this fact in the development of didactic manuals.

The following question was asked to find out what sporting activities children practised most often. We tried using the obtained information to adapt the didactic manuals focusing on physical activity accordingly. Through their most popular physical activities or sports games, we made the pupils familiar with the principles of good sport (maximum heart rate, energy supply, amount of physical activity, etc.). The girls' prevailing activity was associated with dancing, which seems an interesting subject for Physical Education lessons, which girls tend to avoid. The boys' range of sporting activities was more varied - they favour different sports games, as well as individual sports like swimming, cycling and martial arts.

The pupils were also asked whether they considered the amount of their physical activity sufficient. Physical activity in terms of its amount is considered adequate by $44 \%$ of the pupils and probably adequate by $42 \%$. Only $2 \%$ of the 
pupils opted for the no answer. Given the results of the second question in which the pupils had been asked to specify the number of hours of physical activity per week and where nearly a half of all the respondents $(47 \%)$ had listed less than 4 hours per week, we concluded from the results that the pupils did not know what was the optimal amount of physical activity per week and, therefore, this issue should be addressed.
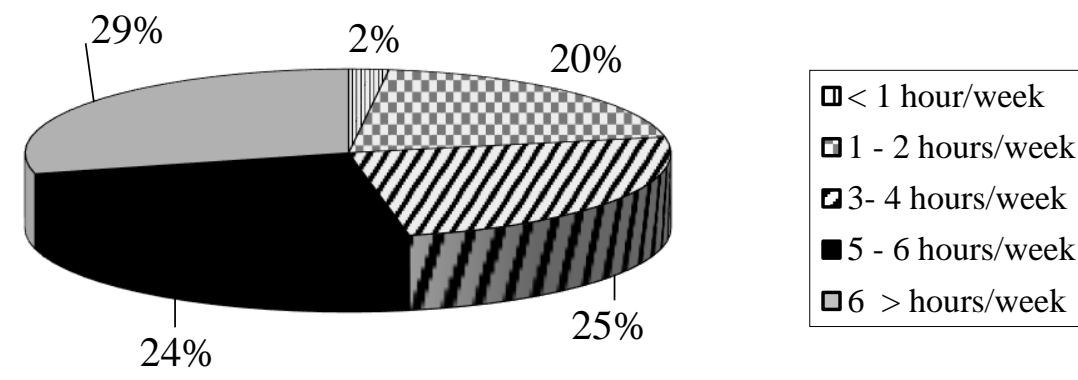

Chart No. 1. Amount of physical activity per week (without school PE)

\section{B. Healthy diet, calorie intake - expenditure}

Another part of the questionnaire investigated pupils' knowledge in the area of healthy diet and how they are familiar with the issues of energy intake and expenditure. The pupils were asked to indicate whether they thought that they and their family were eating good food.

In the majority of the cases - $96 \%$, the pupils answered that they thought they had healthy eating habits with their family (of them $56 \%$ chose the answer probably yes). Only $4 \%$ of the pupils chose the response "I don't know".

In the next question, the pupils had a list of 20 food items and their task was to choose those which corresponded to a healthy diet. The pupils got instructions to choose "the healthiest foodstuffs". The surprising conclusion was that only three pupils were able to answer quite correctly. The most frequent mistake was marking a sweet with vitamin $\mathrm{C}$ or biscuits as health food. Most of the children were able to identify at least two food items meeting the above criteria. The results reached by the children in this question indicated that this topic must be addressed during Health Education lessons. While evaluating the questionnaires pupils themselves said that they were very interested in this topic and showed great enthusiasm for future work. 
The following question examined the knowledge of the effect of the ratio of the energy received in food and the energy given out during the day through physical activity. The responses to this question indicated that the pupils were not very strong on this issue. $22 \%$ of the children listed that they knew what effect the ratio of energy intake and expenditure would have, while the same percentage $(22 \%)$ chose the option no, therefore, they have no knowledge on this issue. $38 \%$ of the pupils wrote that they probably knew what influence the energy intake expenditure ratio had on their body. The results reached by the pupils in this question were surprising. The issues of energy intake and expenditure are often discussed in the media (television programmes, daily newspapers, youth magazines, etc.) and are one of the basic factors for maintaining the optimal body weight.

The next question directly followed the previous one. The pupils were asked to write whether they knew how to calculate their calorie intake during one day. A total of $50 \%$ of the pupils do not know how to calculate their total caloric intake, and this answer was chosen by all the pupils who did not know or probably did not know about the effect of the calorie intake and expenditure ratio on their body. Only $2 \%$ of the pupils could handle this issue, and $15 \%$ of the pupils wrote that they would probably know how to calculate their total energy intake per day.

During the common evaluation of the results achieved by the pupils in the questionnaire, the pupils said in the discussion that "something like that cannot be calculated at all". In the didactic manuals, we included this issue very often and pupils had a chance to calculate the calorie intake by solving numerous practical problems (e.g. they calculated the total energy intake from food bought in a fast food type of restaurant or the energy intake of an individual suffering from anorexia).

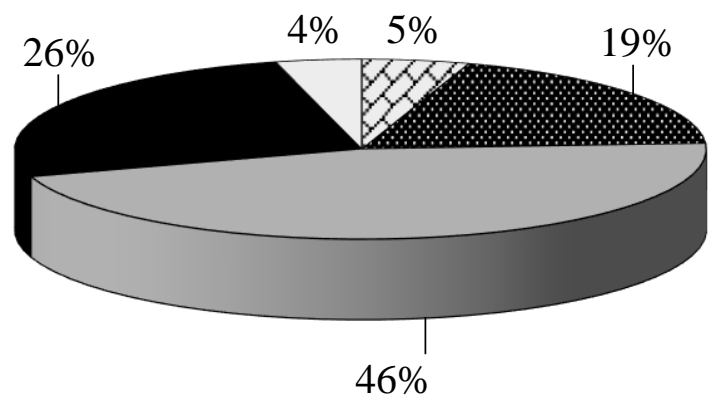

$$
\begin{aligned}
& \text { घ0 mistake } \\
& \text { 1 - } 2 \text { mistakes } \\
& \square 3-4 \text { mistakes } \\
& \square 5 \text { - } 6 \text { mistakes } \\
& \text { 7 a > mistakes }
\end{aligned}
$$

Chart No. 2. Mistakes in choosing health food 


\section{Eating habits}

The following part of the questionnaire was devoted to pupils' eating habits. For specific food items, we identified the frequency of their consumption, and one question addressed fast food type eating.

Table 1. Eating habits

\begin{tabular}{|l|l|c|c|c|c|}
\hline Consumption & Sex & \multirow{2}{*}{ Not at all } & \multirow{2}{*}{ x daily } & 2 x daily & More often \\
\hline \multirow{2}{*}{ Food stuff } & Lemonade & 12 & 40 & 10 & 38 \\
\cline { 2 - 6 } & Goys & 8 & 53 & 23 & 16 \\
\hline \multirow{2}{*}{ Water } & Boys & 8 & 30 & 29 & 33 \\
\cline { 2 - 6 } & Girls & 0 & 28 & 17 & 55 \\
\hline \multirow{2}{*}{ Fruit } & Boys & 6 & 38 & 32 & 24 \\
\cline { 2 - 6 } & Girls & 0 & 20 & 48 & 32 \\
\hline \multirow{2}{*}{ Vegetables } & Boys & 3 & 50 & 37 & 10 \\
\cline { 2 - 6 } & Girls & 0 & 28 & 47 & 25 \\
\hline \multirow{2}{*}{ Sweets } & Boys & 23 & 44 & 3 & 30 \\
\cline { 2 - 6 } & Girls & 0 & 67 & 23 & 10 \\
\hline \multirow{2}{*}{ Smoked-meat products } & Boys & 30 & 38 & 12 & 20 \\
\cline { 2 - 6 } & Girls & 0 & 78 & 10 & 12 \\
\hline \multirow{2}{*}{ Meat } & Boys & 18 & 50 & 18 & 14 \\
\cline { 2 - 6 } & Girls & 8 & 74 & 16 & 2 \\
\hline
\end{tabular}

Based on the identified facts, we adapted the didactic manual so that the pupils would realize what mistakes they made in their eating habits and in which way these bad habits were hazardous for their health.

The results clearly show that the pupils have a variety of bad eating habits. During the subsequent common analysis of the results from the questionnaires and a joint discussion it turned out that e.g. the children considered lemonade to be part of the drinking regime ("it's made of water, isn't it?") and do not realize the numerous substances hazardous to their health which are included in lemonade. Likewise, the children had no idea what danger regular consumption of smokedmeat products meant for them and wanted to learn more about this issue. The encouraging finding is the fact that the children do not avoid fruit and vegetables and try to incorporate them in their diet at least once a day. Once a day, $44 \%$ of the boys and $67 \%$ of the girls eat sweets. During the discussion about the type of meat which the children most frequently eat, the pupils often said that they "did not know" and that "it does not matter what meat they eat, the main thing is they eat some". A total of 5 boys and 2 girls do not eat meat at all, which may be dangerous especially for children in this age category. The information that we learned from the table above became very valuable later during the compilation of the didactic manual. It became a kind of "springboard". We take a lot of knowledge about healthy diet for granted (even children often pretend to "know it all"), but the questionnaire presented to the pupils revealed a number of 
uncertainties with which the pupils struggle and which should be explained to them.

The next question in the questionnaire investigated how often children preferred food from a vending machine or a fast food restaurant to normal food (lunch in the school canteen, snack brought from home ...). The worrying finding is that $53 \%$ of the pupils will swap, for example, lunch in the school canteen or a snack from home for the above type of food. The joint discussion devoted to this issue revealed that the pupils had no idea "why eating at fast food restaurants once or twice a week is dangerous". The pupils also said that "the food at fast food restaurants is tasty and looks much better than lunches in the school canteen and that's why they think it is healthier".

\section{Body care}

Another three questions of the questionnaire investigated the topic of body care. The questions specifically addressed the issues of food intake disorders, personal hygiene principles and terms of self-concept and self-knowledge.

The question focused on the topic of food intake disorders identified the knowledge of what the food intake disorder is and the ability to distinguish the signs of this disease in a friend. $24 \%$ of the pupils wrote that they knew such diseases and would know how to help a friend. $44 \%$ of the pupils think that they probably know what kind of disease it is. Conversely, $8 \%$ of the pupils could not imagine anything under this term and so chose the answer no. $14 \%$ of the pupils have never heard this term and $10 \%$ of the pupils have little knowledge of it.

The knowledge of personal hygiene was evaluated very high by the pupils.

Table 2. Knowledge of personal hygiene principles (\%)

\begin{tabular}{|l|c|c|c|}
\hline \multicolumn{1}{|c|}{ Personal hygiene principles } & Sex & Yes & No \\
\hline \multirow{2}{*}{ Do you always wash your hands after using the toilet? } & Boys & 97 & 3 \\
\cline { 2 - 4 } & Girls & 100 & 0 \\
\hline \multirow{2}{*}{ Do you wash your hands before every meal? } & Boys & 27 & 73 \\
\cline { 2 - 4 } & Girls & 70 & 30 \\
\hline \multirow{2}{*}{ Do you change your underwear daily? } & Boys & 75 & 25 \\
\cline { 2 - 4 } & Girls & 100 & 0 \\
\hline \multirow{2}{*}{ Do you brush your teeth daily? } & Boys & 92 & 8 \\
\cline { 2 - 4 } & Girls & 100 & 0 \\
\hline \multirow{2}{*}{ Do you comb your hair every morning? } & Boys & 53 & 47 \\
\cline { 2 - 4 } & Girls & 100 & 0 \\
\hline \multirow{2}{*}{ Do you take a shower or a bath every day? } & Boys & 90 & 10 \\
\cline { 2 - 4 } & Girls & 97 & 3 \\
\hline
\end{tabular}

The pupils practise personal hygiene sufficiently, potential transgressions against the principles stem from laziness rather than ignorance. During a joint BEÜ SBE Derg. • 5:2 (2016) • ss. 55-74 
discussion, the pupils, for example, said that "combing hair is a waste of time". An "unkempt" pupil does not represent such a problem as the fact that 15 boys from a total of 24 and 12 girls from a total of 29 do not wash their hands before eating. The pupils commented that "at school it is a problem, because it is not possible to wash hands in front of the canteen". The question why they do not wash their hands before eating at home, where they certainly have adequate conditions to do so, could not be argued by the pupils, and together we concluded that laziness and forgetfulness were a bigger problem than the inability to wash their hands before entering the canteen. As a follow-up to the discussion, collaboration with a Natural History teacher was established who made the pupils familiar with the microorganisms living on unwashed hands within the framework of interdisciplinary links. The pupils learned about potential health risks in the case of ignoring the principles of personal hygiene.

\section{E. Knowledge of terms self-concept and self-understanding}

Here, as expected, the pupils were not sure about their answers and for the majority of them the two words were new. For $40 \%$ of the pupils, these two concepts are new and $34 \%$ of the pupils think that they have probably never heard these two words before. $10 \%$ of the children wrote they had heard these two terms, but as we found out during the common evaluation of the questionnaires they were not able to define them. $15 \%$ of the pupils chose the answer probably yes, and later, during the discussion, these pupils said that e.g. "they had heard one of the two words, but they did not know how to explain it". While writing the didactic manuals we took the above results into account and the concepts were explained and practised through a variety of techniques (drawing, questionnaires, and interviews with classmates).

The last question was intended to find out what the children thought that they would learn in the subject. The pupils most frequently expected to enrich their knowledge regarding health food, healthy lifestyle, what diet is appropriate and what diet is inappropriate for them. Not once did the pupils mention options such as self-knowledge, none of them thought they could learn information about drugs, lifestyle diseases, etc. 


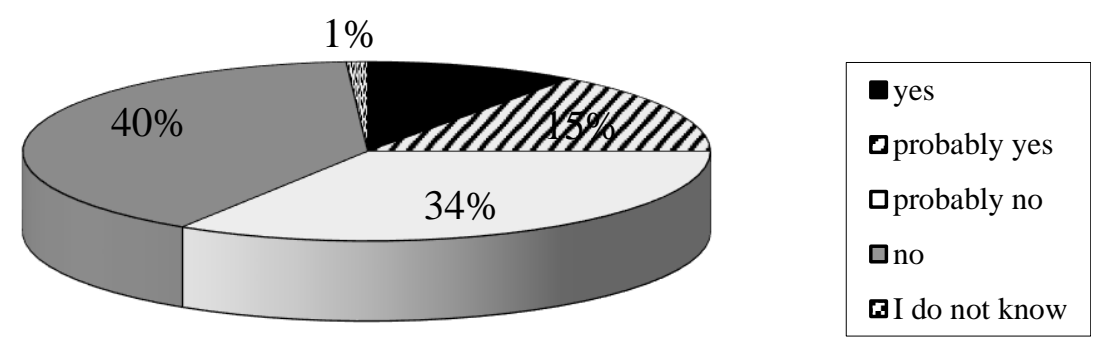

Chart No. 3. Knowledge of terms of self-concept, self-understanding

\section{Resulting comparison of knowledge of $7^{\text {th }}$ and $9^{\text {th }}$ grades}

The knowledge of the seventh-grade pupils who had completed the 5month learning with the help of the didactic manuals complied by us was compared with the knowledge of pupils in the ninth grade. The ninth-grade pupils were not disadvantaged against the "seventh graders". The subject matter to which the seventh-grade pupils had devoted themselves intensively for half a year had been studied by the "ninth graders" throughout the whole three years in subjects like Biology and Chemistry. They had attended a series of lectures on topics addressed by the didactic manuals. We may, therefore, assume that the knowledge of ninth-grade pupils should be at least on the same level (or even better) as in the seventh grade.

The ninth-grade pupils only conducted the final questionnaire survey. The pupils' knowledge on healthy diet and healthy lifestyle were comparable. In the seventh grade, $26 \%$ managed to accomplish the task without mistakes, while in the ninth grade it was $24 \%$ of the pupils. Likewise, very slight differences were found in the number of respondents with one mistake. In the seventh grade, there were $59 \%$, and in the ninth grade $53 \%$ of them. Regarding two mistakes, the differences are greater - the seventh grade pupils made two mistakes in $11 \%$ of the cases, while the ninth grade ones in $21 \%$. Three or more mistakes did not occur in either of the grades.

The next question was designed to find out the knowledge of the ninthgrade pupils on the topic of food intake disorders. Their results were subsequently compared with the results of the seventh-grade pupils. In $65 \%$ of the cases, the ninth-grade pupils were familiar with the issues of food intake disorders and answered the whole question correctly. In $21 \%$ of the pupils from the same grade, uncertainties were identified, which again, like in the seventh-grade pupils, related to the forms of help in the case someone very close suffered from this disorder. 8 $\%$ of the pupils failed to distinguish bulimia and $14 \%$ of the ninth-grade pupils failed to answer this question at all. The seventh-grade pupils reached 
significantly better results in this question during the output questionnaire survey where the number of successful respondents (the whole question is correct) was by $25 \%$ higher than in the case of the ninth-grade pupils. The same applied to wrong answers when the "seventh graders" had by $10 \%$ fewer unsuccessful respondents.

In the question verifying the knowledge of the terms of self-concept and self-understanding, the seventh-grade pupils were significantly more successful than the ninth graders. The seventh-grade pupils were able to respond quite correctly in $72 \%$ of the cases, while the ninth-grade pupils only in $24 \%$. The seventh-grade pupils were also significantly better in terms of the number of pupils who could not answer the question. Among the seventh-grade pupils, a total of unsuccessful pupils equalled $13 \%$, while in the ninth grade it was $70 \%$.

Also, the ninth-grade pupils had much greater problems answering the question checking the pupils' knowledge on healthy diet than the seventh-grade pupils. Individual floors of the food pyramid were correctly filled in by $3 \%$ of the pupils from the ninth grade and $40 \%$ of the pupils from the seventh grade. $76 \%$ of the ninth-grade pupils and $48 \%$ of the seventh-grade pupils were unable to fill in the food pyramid. The seventh-grade pupils again proved better knowledge than the pupils from the ninth grade.

The making of a menu reflecting the principles of healthy diet was a simpler task for the ninth-grade pupils than filling in individual floors of the food pyramid. $52 \%$ of the pupils in the ninth grade set up the menu correctly (choosing the right food, balanced diet, caloric value). The menus of the seventh-grade pupils were in order in $76 \%$ of the cases. The menu was partially correctly made by $24 \%$ of the ninth-grade pupils and $14 \%$ of the pupils in the seventh grade. The menu was not set up by $24 \%$ of the pupils from the ninth grade and $10 \%$ of the pupils from the seventh grade.

In the next question of the final questionnaire survey, the pupils merely filled in words applying their knowledge acquired in the block dedicated to a healthy diet and healthy lifestyle again. Here, their task was to critically evaluate their own eating habits, identify mistakes and propose a solution that would benefit their health. While filling in the words in the text, the greatest problem for the ninth-grade pupils was the optimum number of the calorie intake for their age group. Some responses (e.g. $2 \mathrm{kcal}, 30 \mathrm{kcal}, 40000 \mathrm{kcal}$ ) show that the pupils do not know what kcal is and why this unit is so important. Only $8 \%$ of the pupils managed to answer correctly, $50 \%$ of the ninth-grade pupils did not know what they should include in their menu so that their diet would be balanced.

Regarding the amount of physical activity, most pupils wrote 1-2 hours of physical activity per day, which can be considered the correct answer; some pupils think that they should be in motion for three hours a day. $8 \%$ of the pupils from the ninth grade managed to complete this task without mistakes, while $25 \%$ 
of the pupils in the seventh grade were successful. One mistake was found in 17 $\%$ of the ninth-grade pupils and $58 \%$ of the seventh graders. Two mistakes were made by $54 \%$ of the ninth-grade pupils and $16 \%$ from the seventh grade. The task was completed with three or more mistakes by $21 \%$ of the pupils in the ninth grade and $16 \%$ of the pupils from the seventh grade.

The majority of the pupils were able to correctly answer where they could find information on the content of kcal in a particular product, but they did not know how to calculate their total daily intake. The pupils know how the received energy is burned, except for a traditional couple of exceptions. One pupil would burn received calories by the lack of sleep, another would dissolve fats and sugars in vitamins, and another student would burn kcal exclusively by thinking. $61 \%$ of the pupils in the ninth grade and $78 \%$ of the pupils in the seventh grade were able to correctly answer the question. Completely wrong answers were submitted by $24 \%$ of the ninth-grade pupils and $6 \%$ from the seventh grade. $15 \%$ of the pupils from the ninth and $16 \%$ of the pupils from the seventh grade answered the question partially. In partial responses, neither the ninth-grade nor the seventhgrade pupils were able to find a way how to calculate the total daily intake of calories. The last question represented a simpler task for the pupils from the seventh grade who scored better results again.

Prominent differences in the knowledge of the pupils in the seventh and ninth grade confirm that the pupils' knowledge can be improved through the didactic manuals and assigning lessons to the subject Health Education.

\section{Discussion}

Obesity is an important public health issue. Finding ways to increase physical activity and improve nutrition, particularly in children, is a clear priority. An emphasis on academic subjects and lack of institutional support are barriers to implementation of Health Education. Stronger alliances between health and education appear essential to intervention success. Researchers must work with schools to develop and implement interventions, and to evaluate their impact on both health and educational outcomes as this may be a key determinant of scalability. Further evaluations of interventions to promote physical activity and nutrition during school age are needed. Finally, process evaluations must move beyond simple measures of acceptability/fidelity to include detailed contextual information to illuminate exactly what works, for whom, in what contexts and why. (Langford, Bonell, Jones, Campbell, 2015).

Our research has offered teachers of the subject Health Education theoretical and practical support for teaching. In its development, we proceeded from experience to practice where the lack of materials and textbooks for this new subject present a big problem, particularly for unqualified teachers of Health 
Education. During expert consultations with teachers of other subjects, the issues of interdisciplinary overlaps repeatedly came up.

The input questionnaires created a good starting point for the development of didactic manuals. Based on the findings, we compiled the didactic manuals so that the information included in them would be neither too trivial nor, on the contrary, too difficult. Based on the identified information, we e.g. authorized pupils to learn body hygiene; after the initial introduction and revision of the personal hygiene principles, they produced information leaflets which they later presented at the first level of primary school (to younger classmates).

The problem encountered during the research was that it was very timeconsuming. The entrance and final questionnaires were filled in by the pupils gradually because of their high absence rates at school. This issue was still more evident in the final questionnaire survey as it took place in February when the pupils were ill or on holiday with their parents.

Despite their "lead" over the children from the seventh grade thanks to their completion of subjects like Chemistry and Biology (particularly the human body topic), the ninth-grade pupils demonstrated a lower level of knowledge. In some questions, the differences were dramatic. The fact that Health Education in the current ninth grade was taught by their form master and, as the pupils say, some of the Health Education lessons were filled with activities, such as checking apology letters, dealing with disciplinary offenses, etc., must have its share in the different levels of knowledge. We assume that if the subject of Education for Health was taught by a qualified teacher, the above "losses" would be avoided. However, this is a general problem of "education" in primary schools - lessons are assigned to teachers to "complement their teaching load" and the teachers, who are overloaded with all sorts of paperwork, gladly use these lessons to do all their leftover work.

While evaluating the questionnaires we found out that the pupils in both grades experienced the greatest problems in filling in individual floors in the food pyramid and the optimal total daily intake of calories. Moreover, the pupils in the ninth grade are still unfamiliar with the terms of self-concept and selfunderstanding.

Many of these findings are congruent with conclusions from other studies examining effective elements of school-based interventions that identify the importance of institutional support, assessment of school needs, ownership of programs, adequate training and tailoring of intervention components to local contexts (Langford, Bonell, Jones, Campbell, 2015). Similar findings regarding intervention development and implementation are also noted in Peters et al.'s recent review of school health promotion (Peters, Kok, Ten Dam, Buijs, Paulussen, 2009) and in guidelines for HPS produced by the International Union for Health Promotion and Education (IUHPE, 2014). Survey reported here are 
congruent with reviews of the wider evidence base (IUHPE, 2014a, b) and contribute to the emerging picture of how best to improve physical activity and nutrition in schools. Implementation trials (including process evaluations) that evaluate the roll-out of successful programs would extend our understanding of how to implement such interventions in 'real world' settings. Our findings raise three challenges for both policy makers and researchers. We need greater integration between health and education (Mohammadi, Rowling, Nutbeam, 2010). As suggested by the findings described above, schools are more likely to engage in health interventions if they fit with institutional priorities, namely improving educational attainment. Overweight and obesity have been found to be associated with poor academic performance (Taras, Potts-Datema, 2005). There is also some evidence to suggest physical activity and nutrition (Trudeau, Shephard, 2008, Murray, Low, Hollis, Cross, Davis, 2007).

\section{Conclusions}

In the research study, we tried elaborating a set of didactic manuals on the topic of body care, self-concept and body self-concept and physical activity in education promoting health for the subject Health Education. After the practical application of the didactic manuals in the seventh grades of primary school, we verified their effectiveness through a final (output) questionnaire survey and made a comparison with the knowledge of pupils from the ninth grade.

The research has shown improvement in pupils' knowledge compared to the input questionnaire survey, with the greatest improvement of knowledge attained by the pupils in the area of self-concept and body self-concept. The results of the seventh-grade pupils from the final questionnaire survey are better than those of the ninth-grade pupils.

The following recommendations seem important and promising for practice:

It is advisable to teach Health Education lessons through practical tasks. The pupils will rather remember what they have tried by themselves than sentences dictated and written into the exercise book and long monologues in front of the blackboard.

- Involve pupils actively in the lesson. Children like to teach their peers (sense of importance) and, on the contrary, classmates are happy to hear what their classmate has made up.

- Constantly look for new information, enrich lessons with various interesting facts.

- Give a lot of space to project work. Try to incorporate interdisciplinary overlaps.

- Think of the fact that Health Education should not only be entertaining for pupils, but it must also entertain the teacher. 
Based on partial research studies of the curriculum for Health Education in 1990-2011, i.e. mainly the results of the monitoring of the educational content of transformations focused on the promotion of health in curriculum documents and the experience in the implementation of the objectives defined in them in primary education, some specific requirements can be formulated which are still highly topical (Fialová et al., 2014).

- $\quad$ Promotion of pupils' health on the part of school as an institution, particularly the process of education focusing on education for health, should accompany primary schools pupils throughout the whole time of their school attendance, and always with respect to their age and individual specificities. This fact adds other variables to the issues of the investigated branch of education whose content is defined for lower secondary education. Links to the primary or pre-primary level of education are necessarily included in a wider field of view.

- Education for health should contribute to solving serious allsociety issues associated with manifestations of insufficient responsibility for one's own health and the health of others, the occurrence of risky behaviour patterns of children and youth. This means that the specific content of the monitored branch has been, is and will always be determined by the current social need, and, at the same time, it should specifically reflect individual needs of pupils.

- Holistic approach to health must be strictly respected in education for health, based on mutual interconnections and affecting its determinants at the physical, mental and social level, creating salutogenic conditions in all areas of school activity, emphasizing the promotion of mental health in the context of risky behaviour prevention.

- A personal example of all teachers and the school staff is of crucial importance in enforcing health promotion. Pupils' motivation for specific health beneficial activities and actions and the consistency in the implementation of jointly adopted behavioural rules in favour of health are important factors.

- The school environment and its surroundings, the school regime, offered activities and events, etc. also play a significant role. It is, therefore, necessary to think about all potential contexts and consider what and to what extent can support or threaten pupils' health and their views on health during the preparation for teaching and during lessons, during the modification of the school environment and the organization of various pupils' activities and school events.

- The content layout of the curriculum of Health Education should respect the natural phases in the physical, psychological and social development BEÜ SBE Derg. • 5:2 (2016) • ss. 55-74 
of pupils with a particularly sensitive approach to pupils in their adolescence. The designed curriculum should, therefore, create such conditions so that the educational content can develop in a spiral, i.e. the basic thematic topics should, to some extent, be repeated in the teaching process, their content, however, should always be wider and deeper adequately to the age and the needs of pupils.

\section{References}

Fialová, L., Flemr, L., Marádová, E., Mužík, V. (2014). Vzdělávací oblast Člověk a zdraví v současné škole. Praha: Karolinum.

Hájková, L. (2012). Výchova ke zdraví na základní škole. Diploma thesis. Praha: UK FTVS.

Holčík, J. (2004). Zdraví 21. Výklad základních pojmů. Úvod do evropské zdravotní strategie Zdraví pro všechny v 21. století. Praha: Ministerstvo zdravotnictví ČR. MSD.

Holčík, J. (2009). Zdravotní gramotnost a její role v péči o zdraví. Brno:

Langford, R., Bonell, CH., Jones, H. And Campbell, R. (2015). Obesity Prevention And The Health Promoting Schools Framework: Essential Components And Barriers To Success. International Journal of Behavioral Nutrition and Physical Activity. 12966-015-0167-7.

Maradová, E. (2007). Prevence dětské obezity jako součást výchovy ke zdraví na základních školách. Výživa a potraviny, 62(5), 68-71.

Maradová, E. (2008a). Education towards Health on the Way from the Framework Education Programme towards its Realization in School Practice. In E. Řehulka et al. (Eds.), School and Health 21 - Contemporary Discourse on School and Health Investigation (pp. 23-28). Brno: Masarykova univerzita.

Maradová, E. (2008b). Výchova ke zdraví v kurikulu školy jako výzva pro změny v edukační realitě. In T. Svatoš \& J. Doležalová (Eds.), Pedagogický výzkum jako podpora proměny současné školy - sborník sděleni 16. konference $\check{C} A P V$. Hradec Králové: Gaudeamus UHK.

Mohammadi, N. K, Rowling, L., Nutbeam, D. (2010). Acknowledging educational perspectives on health promoting schools. Health Educ; 110(4), 240251.

Murray, N. G., Low, B. J., Hollis, C., Cross, A. W., Davis, S. M. (2007). Coordinated School Health Programs and Academic Achievement: a Systematic Review of the Literature. J Sch Health; 77(9), 589-600.

Mužík, V. (2007). Výživa a pohyb jako součást výchovy ke zdraví na základní škole. Brno: Paido.

Mužíková, L. (2010). Škola a zdravi 21. Podněty pro implementaci výchovy ke zdraví do školnich vzdělávacich programů. Brno: Masarykova univerzita. 
Peters, L., Kok, G., Ten Dam, G., Buijs, G., Paulussen, T. (2009). Effective elements of school health promotion across behavioral domains: a systematic review of reviews. BMC Public Health;9 (1):182. doi: 10.1186/14712458-9-182.

Průcha, J., Walterová, E., Mareš, J. (2013). Pedagogický slovník. Praha: Portál.

SPE. (1995). Standard základního vzdělávání. Praha: Fortuna.

Taras, H., Potts-Datema, W. (2005). Obesity and Student Performance at School. J Sch Health; 75(8), 291-295.

Trudeau, F., Shephard, R. (2008). Physical education, school physical activity, school sports and academic performance. Int J Behav Nutr Phys Act.; $5(1), 10$.

\section{Internet sources:}

FEP PE. Rámcový vzdělávací program pro oblast Člověk a zdraví Ministerstva školství, mládeže a tělovýchovy. Online 9.4.2011. Retrived from http://www.msmt.cz/vzdelavani/ramcovy-vzdelavaci-program-pro-zakladnivzdelavaniverze-2007.

FEP PE. Rámcový vzdělávací program pro základní vzdělávání - verze 2007

(platná verze). Online 23.8.2011. Retrived from
http://www.msmt.cz/vzdelavani/ramcovyvzdelavaci-program-pro-zakladnivzdelavani-verze-2007.

IUHPE (2008a). Achieving health promoting schools: guidelines for promoting health in schools. Version 2 of the document formerly known as "Protocols and guidelines for health promoting schools". International Union for Health Promotion and Education 2008. Retrived from http://www.dhhs.tas.gov.au/_data/assets/pdf_file/0011/115895/guidelines_for_he alth_promoting_schools 1.

IUHPE (2008b). Promoting Health in Schools: From Evidence to Action. International Union for Health Promotion and Education. Retrived from http://www.iuhpe.org/images/PUBLICATIONS/THEMATIC/HPS/EvidenceAction_ENG.pdf.

PERNICOVÁ, H. Vzdělávací oblast oboru Výchova ke zdraví. Online 23.8.2011. Retrived from http://www.rvp.cz/clanek/250/610.

Školní vzdělávací plan. Online 23.8.2011. Retrived from http://www.zs2.plzenedu.

World health organization. Office for Europe. Obesity Online 30.1.2012. Retrived from

http://www.euro.who.int/en/what-we-do/healthopics/noncommunicablediseases/obesity.

World health organization. Office for Europe. Nutrition. Online 30.1.2012. Retrived from [http://www.euro.who.int/en/what-we-do/healthtopics/diseaseprevention/nutrition/a-healthy-lifestyle/body-mass-index-bmi. 
